\title{
KANSANSIVISTYSMIES JA HUMANISTI ISMA MÄKELÄ IN MEMORIAM
}

$\mathrm{K}$

ansan Sivistystyön Liiton entinen pääsihteeri Isma Mäkelä poistui elämän näyttämöltä Espoossa 21.10. Hän oli syntynyt Kauhavalla vuonna 1934.

Isma Mäkelän elämässä oli määräävinä kolme ajattelun suuntaa, jotka rinnakkaisina ja päällekkäisinä määräsivät miehen mietteet ja käytännön toimet. Sosialistinen aatteellisuus tuli jo kotikasvatuksen myötä. Se tarkoitti pyrkimystä oikeudenmukaiseen yhteiskuntaan ja ihmisten tasa-arvoon; jokaisella ihmisellä on oikeus työhön ja toimeentuloon ja samalla oikeus sivistykseen ja kulttuuriin. Kansainvälisyys, jota sanottiin myös sosialistiseksi internationalismiksi, lähti siitä, että kansat ovat veljiä keskenään ja tämän veljeyden pohjalle rakentuu pysyvä rauha maailmassa. Kolmas ajattelun suunta oli suomalaisuus ja siitä täsmentynyt pohjalaisuus ja kauhavalaisuus.

Isman äiti, Helvi, oli jäyhää kauhavalaista Jylhän sukua. Isä Aatos taas oli Vimpelin Sääksjärven Mäkelöitä. Isoisä, Santeri Mäkelä, oli aikoinaan innokas nuorisoseuramies, Santeri Alkion ystävä ja aatetoveri, mutta oli Amerikan matkalla omaksunut sosialistisen ajattelutavan. Perehtyminen sosialistiseen kirjallisuuteen ja omat kaunokirjalliset harrastukset syvensivät ajattelua niin, että Santerista tuli pidetty puhuja Amerikan suomalaisen työväenliikkeen tilaisuuksiin. Kotimaahan palattuaan hän toimi kotikylän työväenyhdistyksessä ja jouti sitä kautta eduskuntaan. Santeri osallistui vuoden 1918 kansalaissodan aikaisen punaisen hallituksen, Kansanvaltuuskunnan toimintaan ja joutui pakenemaan Neuvosto-Venäjälle. Sille tielle hän jäikin.

Isman isä Aatos Mäkelä oli armoitettu lausuja ja teatterimies. Senpä vuoksi Mäkelöiden perheessä työväen kulttuuriharrastus oli jokapäiväistä leipää, tai ainakin leivän särvintä. Kauhavan työväentalon näyttämö oli Ismalle tärkeä kulttuuri-instituutti heti sodan jälkeen. Nuorimmasta veljestä, Vesa Mäkelästä, tuli tunnettu näyttelijä. Vesan poika Aleksi Mäkelä toteuttaa suvun lahjakkuutta elokuvaohjaajana.

Nuoruudessaan Isma teki muurarin ja rapparin töitä isä-Aatoksen kanssa, kunnes lähti opiskelemaan Sirola-opistoon ja sen jälkeen oli lahjakkaalle miehelle tarjolla tehtäviä kansandemokraat- tisessa liikkeessä. Hän työskenteli mm. Unkarin radion toimittajana Budapestissa. Näin Isma Mäkelä oli paikalla seuraamassa Unkarin veristä kansannousua ja sen kovakouraista kukistamista - yhtenä harvoista suomalaisista silminnäkijöistä.

Isma perehtyi unkarin kieleen ja kulttuuriin ja siitä tuli hänelle kestävä harrastuksen ja rakkauden kohde. Unkarin vuosia seurasi opiskelu Moskovassa ja kääntäjänä APN-uu-

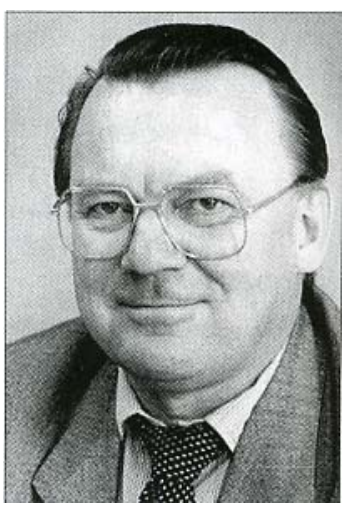

Isma Mäkelä

Kuva: Pekka Pajuvirta tistoimistossa. Uutena harrastuksena tuli kuvataide, piirustus ja kuvanveisto.

Isma teki mittavan päivätyön aikuiskoulutuksen kehittäjänä, KSL:n kirjeopiston johtajana ja pääsihteerinä, Espoon kaupungin työväenopiston johtokunnan puheenjohtajana ja Valtion kansansivistyslautakunnan jäsenenä. Tuona aikana tuli voimaan opintokerholaki, opintokeskuslaki ja niiden myötä omaehtoinen opiskelu ja kulttuuritoiminta sai valtiovallan tunnustuksen. Kansansivistystyön ja aikuiskoulutuksen toimijat löysivät laajasti yhteisen sävelen, oppivat yhteistyön taitoja ja arvostamaan toisiaan. Se kaikki oli kovasti Isman mieleen.

Isman rakkaus Pohjanmaahan ja Kauhavaan oli sitä, että hän rakasti pohjalaista puheenpartta, tunsi ja osasi harvinaisen paljon pohjalaisia lauluja. Kun Isma lauloi laulun Ketoolan Jukasta ja Ylisen Maijasta, oli siinä tunnetta ja tulkintaa. Usein kuulijoidenkin “...sinisistä silimistä vereet tippuu punaasia poskia pitkin.”

Isman muisto säilyy pitkään ystävien mielessä, hänen työssään, tauluissa ja veistoksissa, lapsissa ja lastenlapsissa ja koko lahjakkaassa Mäkelän suvussa.

\section{Veikko Väntänen}

Kirjoittaja oli Isma Mäkelän ystävä ja työtoveri työskennellen Kansan Sivistystyön Liitossa kulttuurisihteerinä. 